\title{
Voces (des-encontradas) en los Encuentros Nacionales de Mujeres en Argentina
}

\author{
Cristina Viano* \\ Universidad Nacional de Rosario
}

\section{Resumen}

Este artículo examina las perspectivas, sentidos y significaciones que distintos grupos de mujeres moldean alrededor de su participación en los Encuentros Nacionales de Mujeres en Argentina. Nos detenemos particularmente en el análisis de las voces de mujeres provenientes de los grupos feministas fundadores de los ENM, en una organización que vinculada al Partido Comunista Revolucionario (PCR) en los años '90 conmovió con su masiva presencia los encuentros (Amas de Casa del País) y en Pan y Rosas, una organización de orígenes más recientes vinculada a un partido trotskista (el Partido de los Trabajadores Socialistas).

\section{Palabras claves:}

Encuentro Nacional de Mujeres, movimiento de mujeres, movimiento feminista, Amas de Casa del País, Pan y Rosas

\begin{abstract}
This article examines the perspectives and meanings that different groups of women molded around her participation in the National Meeting of Women in Argentina. We stop particularly in the analysis of women's voices from the founders of NMW, feminist groups in an organization linked to the Revolutionary Communist Party (PCR) in the 90s they moved with her massive presence encounters (Homemakers country) and Bread and Roses, an organization of more recent origins linked to a Trotskyist party (Socialist Workers party).
\end{abstract}

\section{Keywords:}

National Meeting of Women, women's movement, feminist movement, Amas de Casa del País, Pan y Rosas

\footnotetext{
Doctora, Licenciada y Profesora en Historia. Docente e investigadora en la Facultad de Humanidades y Artes de la Universidad Nacional de Rosario, Argentina, donde se desempeña como Profesora Titular en Problemática Histórica y como Profesora Adjunta en Historia de América III. Es coordinadora del Centro Latinoamericano de Investigaciones en Historia Oral y Social (CLIHOS) y Profesora en la Maestría Poder y Sociedad desde la Problemática de Género donde dicta el Seminario Movimientos Sociales Contemporáneos. Autora de numerosos trabajos sobre historia argentina reciente, mujeres y movimientos sociales, ente ellos Miradas sobre la Historia. Fragmentos de un recorrido en Prohistoria Ediciones y Des-bordando los márgenes. El movimiento de mujeres en el Gran Rosario, bajo su coordinación en Homo Sapiens ediciones (en prensa).
} 


\section{Voces (des-encontradas) en los Encuentros Nacionales de Mujeres}

\section{A modo de breve presentación 1}

En Argentina, el movimiento de mujeres ha adquirido un protagonismo que no ha cesado de incrementarse, transformarse y re-significarse a lo largo de los años transcurridos entre el fin de la última dictadura militar y la actualidad al punto de constituirse en una presencia relevante de la escena política y social. Un haz de problemas ha cobrado visibilidad y se ha incorporado en la agenda y el debate público y político como producto de su andar y por la fuerza de una multidireccional experiencia transitada entre la que se cuenta en un lugar de significación la realización del Encuentro Nacional de Mujeres (en adelante ENM). Esta iniciativa, pensada y concretada en 1986 por pequeños grupos de feministas cuando los miedos que había impuesto la dictadura eran muy palpables aún, constituyó el comienzo de una tradición que se recrea cada año en distintos puntos de la geografía nacional ${ }^{2}$.

Ya hacia mediados de los años '90 los encuentros devinieron fuertemente heterogéneos, principalmente por la afluencia de mujeres que se proyectaban desde el amplio universo de movimientos sociales que germinó a la sombra del neoliberalismo. Comenzaba también a verificarse un proceso de crecimiento en la participación que se intensificaría en torno a la rebelión de diciembre del 2001: las apenas mil mujeres que un centro cultural porteño (el San Martín) había podido albergar en aquel lejano 1986, devinieron en miles y miles de voluntades que se dan cita cada año durante tres días de manera autónoma y horizontal ${ }^{3}$.

\footnotetext{
${ }^{1}$ Vaya todo mi agradecimiento al conjunto de mujeres que prestaron su tiempo para compartir sus recuerdos, sus vivencias, sus impresiones, sus ideas. También estoy en deuda con Andrea Andújar por la atenta y generosa lectura que realizó a este artículo. Asimismo es importante dejar constancia que éste se inscribe en un proceso colectivo de investigación sobre el Movimiento de Mujeres en las últimas décadas, para el cual hemos realizado aproximadamente 50 entrevistasalgunas con re- pregunta posterior- a mujeres de distintas organizaciones sociales y políticas.

2 Sin pretensión de exhaustividad señalamos algunos textos que abordan de manera central o más oblicua a los ENM: una reconstrucción del primer Encuentro se aprecia en Maffía Diana, Peker Luciana, Moreno Aluminé y Laura Morroni editoras. Mujeres pariendo historia. Cómo se gestó el Primer Encuentro Nacional de Mujeres. Reseña íntima y política de las integrantes de la Comisión promotora. (Imprenta de la Legislatura de la CABA, Buenos Aires, 2013). Para un recorrido sobre los ENM se puede consultar Alma Amanda y Paula Lorenzo; Mujeres que se encuentran. Una recuperación histórica de los Encuentros Nacionales de Mujeres en Argentina (1986-2005), (Feminaria Editora, Argentina, 2009) y para un análisis de los ENM en tanto evento crítico donde el feminismo con sus propias tensiones y complejidades, se pone en escena en un espacio de mujeres (y no solo de feministas) ver Masson, Laura; Feministas por todas partes. Una etnografía de espacios y narrativas feministas en Argentina. Prometeo libros, Buenos Aires, 2007. También Graciela Di Marco desde el análisis generizado de movimientos de trabajadores desocupados y de empresas recuperadas y autogestionadas aborda los ENM. Ver El Pueblo feminista. Movimientos sociales y lucha de las mujeres en torno a la ciudadanía. Editorial Biblos Sociedad, Buenos Aires, 2011. Existe además un caudal de artículos que desde largo tiempo atrás vienen desgranando distintos aspectos de los encuentros y de los que no podemos dar cuenta aquí.

3 Si bien la cantidad de participantes oscila y los datos no son en ocasiones coincidentes señalemos que para el encuentro de San Juan en 1997 la prensa estimó en 8000 la asistencia y cuatro años después para el de La Plata (2001) las organizadoras lo hicieron en 15000. Ver Alma A. y P. Lorenzo; op. cit.
} 


\section{Cristina Viano}

Persiguiendo las huellas del movimiento de mujeres a través de ese mirador excepcional que constituyen los encuentros, este trabajo tiene la modesta pretensión de adentrarse en los sentidos y significados que poseen las experiencias, perspectivas y expectativas moldeadas alrededor de esa participación en los ENM para mujeres pertenecientes a espacios sociales y organizacionales diferenciados que se manifiestan en este tiempo presente y que expresan (solo en parte) la diversidad que hoy habita tanto al encuentro como al movimiento de mujeres. Nos ocupamos exclusivamente de indagar en las percepciones de mujeres provenientes de tres ámbitos distintos: aquellas de los grupos feministas fundadores de los ENM, otras que forman parte de una organización vinculada al Partido Comunista Revolucionario (PCR) y que, si bien presentes desde los '80, en los años '90 conmovieron con su masiva presencia los encuentros (Amas de Casa del País) y finalmente, militantes de Pan y Rosas, una organización que nacida en el 2003 está vinculada a un partido trotskista (el Partido de los Trabajadores Socialistas).

\section{Voces des-encontradas: las feministas históricas, Amas de Casa del País, y Pan y Rosas.}

Durante el primer período post dictatorial, el protagonismo de las mujeres supuso entre otras acciones la salida del movimiento feminista a las calles y que muchos asuntos considerados históricamente de naturaleza privada ingresaran al espacio público. También se sentarían las bases para los nuevos lenguajes y categorías con que más adelante se pondría nombre a situaciones silenciadas y extendidas por las que atravesaban las mujeres. Asomaba a la acción colectiva una generación de feministas (hoy son las "históricas" del movimiento) ${ }^{4}$ que se caracterizó por haber tenido acceso (en su mayoría) a la educación universitaria, fueron y son docentes de distintos niveles, abogadas, psicólogas, médicas, sexólogas, ensayistas, periodistas. ${ }^{5}$ Parte de ese activismo se plasmó en heterogéneas instancias organizativas, la conformación de incipientes ONGs, centros académicos y espacios de articulación tanto como en experiencias marcadamente autónomas. Y si bien ese momento fue particularmente prolífico en la creación de espacios y en la toma de iniciativas conjuntas, cabe destacar algo que una y otra vez se nos ha señalado: "éramos muy pocas"6.

\footnotetext{
${ }^{4}$ Hemos abordado este tema en Bortolotti Mariana, Figueroa Noelia y Cristina Viano; “Los años '80. Los primeros pasos de una nueva etapa" en Viano Cristina (coord.); Des-bordando los márgenes. El movimiento de mujeres en el Gran Rosario. Homo Sapiens ediciones, Rosario, 2014. En prensa.

${ }^{5}$ Los relatos sobre los caminos que cada organización fue asumiendo constituyen un piso común de sentidos que nos hablan de años difíciles en los cuales la capacidad de alterar la persistente rutina patriarcal y comenzar a desbrozar el camino les reclamó ingentes esfuerzos y colaboración entre grupos.

6 Esta etapa implicó que se dieran los primeros pasos para la incorporación de políticas públicas específicas (no encuadradas en tema familia o cuidado) y también constituyó un avance en la conquista de derechos para las mujeres. Al respecto puede consultarse Anzorena, Claudia; "De
} 
Esta generación de feministas que asomó con la recuperación democrática provenía de campos experienciales diversos, que se extienden desde aquellas que se iniciaron en un camino militante en los grupos feministas de los primeros años '70, a otras que se habían sumado a las organizaciones políticas y político-armadas del período, que vivieron la experiencia del exilio externo e interno durante la dictadura e intentaron luego reconstruir intervenciones políticas cuya especificidad las fue derivando en asumirse feministas. También estuvieron otras que formando parte de una similar franja etaria que las anteriores solo participaron episódicamente en la vida política (y lo hicieron en espacios diversos). Se sumarían pronto mujeres que con pocos años menos despliegan en la militancia feminista sus primeros intentos organizativos. En general y a diferencia de las militantes feministas que posteriormente harían su irrupción, esta primera generación en muchos casos "ya no era tan joven" y "venía de una previa muy combativa". Ellas fueron quienes gestaron principalmente los ENM7.

Encuentros que para mediados de los años '90 -y muy acusadamente desde el 2001- han incorporado a un creciente número de mujeres en muchos casos de sectores muy sumergidos. Al decir de una entrevistada “(...) un feminismo urbano, blanco y de clase media... hoy cada vez más aparecen feministas indígenas, campesinas y de sectores populares" que se expresan a través de organizaciones socio territoriales, culturales, partidos de izquierda o espacios sindicales. Ello obedece a que como respuesta a la salvaje lógica neoliberal imperante, se gestaron en distintas geografías del territorio nacional novedosas experiencias de auto organización que, surgidas en muchas ocasiones de las más duras condiciones, lograron generar y sostener espacios de resistencia y construcción social alternativos al modelo dominante.

Los movimientos sociales y las acciones de protesta se diversificaron notablemente hacia la segunda mitad de la década del ' 90 y se convirtieron en una referencia constante de la vida cotidiana. Las mujeres adquirieron un intenso protagonismo en ese ciclo de conflictividad social que surgía en la Argentina, dotando de nuevos registros simbólicos y políticos a un conjunto de

ciudadanas a administradoras. Reflexiones en torno a la relación entre mujeres y Estado en los últimos 25 años en Argentina" en Espinosa Miñoso, Yuderkys (coord.) Aproximaciones críticas a las prácticas teórico-políticas del feminismo latinoamericano. Vol. 1. En la frontera, Buenos Aires, 2010.

${ }^{7}$ El ENM encuentra sus antecedentes en un conjunto de acciones: la solicitada que mil mujeres le escribieron a la dictadura en 1982 con el propósito de abolir el Servicio Militar Obligatorio, la reconstrucción de la geografía de los lugares donde las mujeres fueron viéndose las caras y haciendo causa común por el divorcio, el cupo u otros derechos. La multisectorial de la Mujer, en 1983, que reunía a militantes de distintos espacios partidarios ocupa un lugar destacado en esos antecedentes, también los encuentros internacionales: ya sea el Primer Encuentro Feminista Latinoamericano en Bogotá, Colombia, en 1981, en donde se declaró el 25 de noviembre como Día contra la Violencia hacia las Mujeres o el Segundo Encuentro Feminista Latinoamericano y del Caribe en Lima, Perú de 1983, que fue autofinanciado y en el que las mujeres iban en representación propia, una característica de autonomía que después se desplegaría en los ENM y que sería objeto de controversias futuras. También la III Conferencia Mundial de la Mujer en Kenia, Nairobi, en 1985, representó una inspiración para la organización del Primer Encuentro por promover la idea del cupo femenino en la representación parlamentaria. Ver al respecto Maffía, Diana, Peker Luciana, Moreno Aluminé y Morroni, Laura editoras. Op.cit. 


\section{Cristina Viano}

organizaciones de contenidos ideológicos y políticos muy heterogéneos. Ampliación y diversificación pueden ser vocablos adecuados para marcar algunas de esas transformaciones que se operaron en el movimiento de mujeres cuando avanzaba la década y la altísima concentración de la riqueza, la desocupación masiva, la precarización laboral y el empobrecimiento sistemático mostraban su fase más dura.

Así cuando los efectos del neoliberalismo se hacían sentir duramente en la sociedad argentina las mujeres cortaron rutas, hicieron piquetes, participaron en asambleas, nutrieron movilizaciones, tomaron tierras, abrieron zanjas y caminos, barrieron calles, fundaron comedores, roperitos, cultivaron huertas y para todo ello salieron del ámbito doméstico y se involucraron en la vida política y pública a partir de distintas organizaciones sociales y políticas; también irrumpieron en los ENM en forma creciente8.

También el movimiento feminista, como parte del más amplio movimiento de mujeres, se diversificó desde esos orígenes connotados por la participación de mujeres de clase media. Esta transformación ocurrida principalmente en las dos últimas décadas ha sido denominada por Laura Masson como "feministas por todas partes" 9 y ha supuesto derivas de distinta naturaleza ya que no solo las mujeres que comenzaron a nutrirlo daban cuenta de una mayor heterogeneidad social y cultural sino que las organizaciones que las albergaban se expandieron en modalidades y número y tendieron a configurar un universo más ancho cuyos contornos son complejos de trazar.

Es precisamente en los ENM $^{10}$ donde se produce el contacto cara a cara del movimiento amplio de mujeres al mismo tiempo que adviene en un vehículo para su propia articulación, organización, fortalecimiento y visibilización. Pero ello no se produjo sin conflictos. Cabe preguntarnos entonces ¿Cómo fue percibida entonces la llegada de miles de mujeres a los ENM, mujeres orientadas por partidos de izquierda, por organizaciones socio-territoriales? Aun advirtiendo que

\footnotetext{
8 "Debo decir, que en el Encuentro Nacional de Mujeres, la cantidad de mujeres pobres, muy pobres, o medianamente pobres, es mayoritaria, claramente" asevera Lucrecia A. Ex diputada provincial del Partido Socialista. Feminista. Entrevista, 2011.

${ }^{9}$ La autora ha subrayado que los ENM constituyen un ritual en el cual las feministas se insertan en un espacio más amplio que el feminista y confrontan e intercambian opiniones y experiencias. Ver Laura Masson; op. cit.

${ }^{10}$ Hasta el presente de escritura de este texto se han realizado los siguientes Encuentros Nacionales (que como se advertirá tuvieron una perfecta continuidad): Buenos Aires (1986), Córdoba (1987), Mendoza (1988), Rosario (Provincia de Santa Fe) (1989), Río Hondo (Provincia de Santiago del Estero) (1990), Mar del Plata (Provincia Buenos Aires) (1991), Neuquén (1992), Tucumán (1993), Corrientes (1994), Jujuy (1995), Buenos Aires (A los 10 años de Encuentros y a 20 años del golpe militar)(1996), San Juan (1997), Resistencia (Provincia de Chaco)(1998), Bariloche (Provincia de Río Negro) (1999), Paraná (Provincia de Entre Ríos) (2000), La Plata (Provincia de Buenos Aires)(2001), Salta (2002), Rosario (2003), Mendoza (2004), Mar del Plata (2005), Jujuy (2006), Córdoba (2007), Neuquén (2008), Tucumán (2009), Paraná (2010), Bariloche (2011) Posadas (Provincia de Misiones) (2012), y el Encuentro XXVIII en San Juan (2013). El correspondiente al año 2014 se realizará en Salta.
} 


\section{Voces (des-encontradas) en los Encuentros Nacionales de Mujeres}

el universo de la militancia feminista no constituye un bloque ${ }^{11}$, ni está exento de desacuerdos y que ello en parte se visualiza en los años '90 en el alto grado de fragmentación y diversidad adelantemos que las relaciones estuvieron y están teñidas por tensiones, críticas y desacuerdos de variada naturaleza (que es necesario historizar) entre quienes se definen como feministas y quienes provienen de otros grupos, ¿cuáles son esos elementos que "perturban", que generan conflictos y a veces duros enfrentamientos?, ¿qué se objeta desde las organizaciones feministas?, ¿con qué argumentos?

La organización política que primero irrumpió en los ENM fue el Partido Comunista Revolucionario ${ }^{12}$ (en adelante PCR), a través de Amas de Casa del País, una organización de mujeres ${ }^{13}$ que creada durante el alfonsinismo salió al espacio público propiciando las marchas de los bolsos vacíos de los días jueves ("los jueves no compre") como medida de protesta frente a los aumentos de precios en el marco del intenso proceso inflacionario de entonces; más tarde (en 1994) lo hizo a través de la Corriente Clasista y Combativa (CCC) que se conformaba como corriente política y sindical orientada por el PCR y dando cuenta de la gigantesca desocupación que asolaba a la sociedad argentina. Ello provocó no pocos cimbronazos entre las antiguas organizaciones militantes feministas; al decir de una entrevistada de los grupos históricos “(...) el PCR tomó la manija de los Encuentros y de esto te estoy hablando 91', 92', 93'”.

En primer lugar tendríamos que referenciar que el carácter de diferencias está muy claramente asumido por las feministas y que en las mujeres de Amas de Casa del País no se juegan figuraciones tan potentes sobre las "otras" (o al menos ello no se ha manifestado abiertamente en el proceso de entrevistas). Relevemos que la ya larga controversia que se arrastra desde los primeros años '70 en las filas del feminismo sobre la doble militancia (en grupos feministas y en partidos

\footnotetext{
${ }^{11}$ Valeria Pita ha sostenido que si los años ' 80 representaron un tiempo de auge, de recuperación de los foros públicos y de visibilidad, la siguiente década, en cambio, constituyó un periodo de repliegue, de defensa de lo conquistado y de profundización de las disputas y tensiones en el interior del movimiento feminista. Ver de la autora "Voces en conflicto, espacios en disputa. Experiencias feministas en la Argentina de los '90" en Feminaria vol. XIII, Buenos Aires, 2007. Por su parte Carmen Teresa García y Magdalena Valdivieso subrayan que en la década del ' 90 el movimiento feminista se academiza y se institucionaliza en América Latina, al tiempo que se expanden las políticas sociales de "equidad de género", los encuentros y proyectos de mujeres financiados por la ONU y los programas de micro-crédito del Banco Mundial para las mujeres pobres, programas "oficiales" que conviven con las variadas iniciativas de grupos de mujeres que luchan por la autonomía. Ver "Una aproximación al Movimiento de Mujeres en América Latina. De los grupos de autoconciencia a las redes transnacionales" en OSAL; CLACSO Año VI № 18, Buenos Aires, 2006.

${ }^{12}$ El PCR ha sido una de las organizaciones que más ha movilizado a mujeres y varones en los momentos en que la desocupación y la pobreza se extendían incansablemente por la Argentina. Además -y esto no es menor- sus organizaciones de masas estuvieron nutridas principalmente por mujeres. Asimismo es preciso relevar que el PCR fundó en los primeros '80 el Partido del Trabajo y del Pueblo (PTP) por la necesidad de contar con un aparato con reconocimiento y personería jurídica, con el que nunca contó desde su fundación en 1968 con excepción del período 1973/76.

${ }^{13}$ En la jerga de algunos grupos se las nomina como "las chinas".
} 


\section{Cristina Viano}

políticos) parece reeditarse aquí en un nuevo capítulo con la incorporación de otras actrices y otros contenidos ${ }^{14}$. Examinemos los argumentos.

Entonces el partido que siempre fue marginal diríamos y de pequeña célula tenían estrategias de irrumpir para ... Y un poco como que molestaba porque en aquella época todo lo partidario era nefasto y para las mujeres pensar que ahí se podía dirimir la cosa partidaria las ahuyentaba. Era el momento realmente de lo social y era el espacio de mujeres con mujeres. De decir "por acá pasa mi subjetividad y qué bueno que a vos te pase lo mismo que a mí". En la vida de Dios ibas a encontrar otro lugar donde podíamos hablar de las mismas cosas de distintos sectores. Eso era lo educativo, lo creativo y lo potencial. Entonces ellas aparecían con determinadas cosas...15.

El relato anterior está connotado por el esfuerzo de pensar la historicidad de unas relaciones y por caracterizar un momento más social que venturoso en apuestas políticas. El desengaño frente a anteriores experiencias de participación política juega un papel de significación que es espejado en la irrupción de esas viejas formas que quieren abandonarse para abrirle paso a otras búsquedas. Es que para muchas ex militantes de las organizaciones político revolucionarias de los años '70, el feminismo expresaba una posibilidad cierta de volver a organizarse frente a la profunda crisis de representatividad de los partidos políticos de entonces.

Una de las críticas más frecuentes de las feministas históricas deviene del hecho de que sea desde el "partido" y no por la acción de las propias mujeres que se impulse la participación orgánica con líneas y directrices precisas de trabajo. Ello se traduce tanto en la disputa por espacios en las comisiones organizadoras de los ENM como por los contenidos de los talleres ${ }^{16}$.

(...) los encuentros han servido como para sumar gente del lugar, yo creo que lo que han tenido como, como cosa importante los encuentros es que... donde han ido...después ha potenciado el movimiento de mujeres... lo que nosotras queríamos

\footnotetext{
${ }^{14} \mathrm{Al}$ respecto pueden consultarse los artículos de Karin Grammático; "Las mujeres políticas y las feministas en los tempranos'70. ¿Un diálogo (im)posible?” y de Alejandra Vasallo "Las mujeres dicen basta: movilización política y organizaciones feministas argentinas en los años '70" en AA.VV; Historia, género y política en los '70, Universidad de Buenos Aires y Feminaria Ediciones, Buenos Aires, 2005.

${ }^{15}$ Mabel B. Militante en los primeros '70, ya en el exilio en Perú se conecta con el movimiento de mujeres e inicia una práctica militante que articula feminismo, educación popular y educación sexual. Entrevista, 2011.

${ }^{16}$ Las desavenencias pasan en ocasiones por caracterizaciones más personales que sin embargo remiten a lugares sociales y a imaginarios respecto de esos lugares. Una pionera del movimiento recuerda cuando fue "acusada" de "intelectual" por las mujeres del PCR. No deja de llamar nuestra atención como "intelectual" es percibido como un insulto por nuestra entrevistada, quien con formación universitaria se coloca en otra posición de sujeta, definiéndose a partir de su trabajo y oponiendo la categoría trabajo a la de intelectual. "yo no era intelectual, trabajaba, mirá todo lo que hice en Ludueña y lo que hice en Juana Azurduy, eh... investigué cosas, empecé a investigar, bueno lo hicimos después con el Área de la Mujer en los distritos". Es interesante subrayar cómo intelectual denota tanto para unas como para otra pertenencia a un sector acomodado. Liliana P.; psicóloga, especializada en educación sexual, feminista, fundadora de Casa de la Mujer. Entrevista 2011.
} 


\section{Voces (des-encontradas) en los Encuentros Nacionales de Mujeres}

es como esparcir semillas viste y lo hecho crecía y crecía y yo creo que en Argentina tiene un movimiento de mujeres muy fuerte... Después del '89 el PCR, que no se llamaba PCR, sino que me parece que se llamaba el PTP (Partido de Trabajadores del Pueblo), no sé si se acuerdan ustedes... El PTP se da cuenta de que... realmente los encuentros nacionales son un semillero y que las mujeres... la lucha por los derechos de las mujeres es algo que tienen que explotar y ahí es cuando se comienzan a meter en la organización... es decir, había mujeres de los partidos en la organización pero no cooptaban, no captaban es decir... el PCR de ahí en más dijo:- esta es la mía... Y si... vos seguís la línea de donde se han hecho generalmente, porque después de acá se hace en Santiago del Estero, que es más captado por el peronismo, después tiene más influencia el PTP o PCR. ... es de ahí donde existen las escuelas de Psicología Social y... asistentes sociales... que es también su semillero, no? Y comienza a llevar en los lugares en las provincias en donde tienen... y lo tratan de captar... y eso lo podes observar en la cuestión de los encuentros cuando hacen esta escisión "mujer y...", como si fuésemos... como si la mujer no estuviese viviendo en esta sociedad, no? Eh... "mujer y trabajo", como si la mujer no trabajara, es... como en todo caso... es el análisis de la mujer sobre el trabajo, análisis sobre la política internacional...17.

Ese ingreso de mujeres de sectores populares organizadas partidariamente trajo consigo además la presencia de varones que "acompañaban" y si bien no participaban del ENM, sí se encargaban de la seguridad de la Marcha que se realiza en cada Encuentro y que constituye, hasta hoy, el momento más convocante. Esa presencia generaba un conjunto de fricciones ya que no solo aparecía como una situación de "apriete" contra mujeres de otras organizaciones sino que también se cuestionaba el hecho de que la seguridad tuviera que aparecer asociada a la presencia masculina y por ende, a una suerte de división del trabajo militante que reproduce un rol tradicional ${ }^{18}$.

Nosotras antes nunca habíamos tenido gente acordonada a los costados con la seguridad. Era una estética, digamos una metodología que traen las piqueteras ¿no?..” Si vos comparas los encuentros actuales o ese encuentro, el último de Rosario con el primero al que yo fui que éramos 1200 mujeres, la mayoría de clase media, abogadas, profesionales, que se yo; la diferencia es muy grande. ${ }^{19}$

Es interesante cómo este relato, argumentando desde un perfil de clase, asocia experiencia piquetera -y ello supone experiencia de mujeres empobrecidas o pobres estructurales, o trabajadoras pobres- con cordones de seguridad

\footnotetext{
17 Mimí Ch.; militante política en los primeros años'70, activista feminista, fundadora de IndesoMujer en 1984 (Instituto de Estudios sociales y jurídicos de la Mujer). Entrevista 2011.

${ }^{18}$ Danièle Kergoat sostiene que la división sexual del trabajo es "la forma de división del trabajo social que se desprende de las relaciones sociales de sexo, histórica y socialmente modulada. Tiene como característica la asignación prioritaria de los hombres a la esfera productiva y de las mujeres a la esfera reproductiva así como, simultáneamente, la captación por parte de los hombres de las funciones con fuerte valor social agregado (políticas, religiosas, militares)". Asimismo, subraya que esa división sexual del trabajo posee dos principios organizadores: el principio de separación (hay trabajos de hombres y trabajos de mujeres) y el principio jerárquico (un trabajo de hombre "vale" más que un trabajo de mujer). Ver de la autora "Division sexuelle du travail et rapports sociaux de sexe". en Hirata, H.; Laborit, F.; Le Doaré, H.; Senotier, D. (coords). Dictionnaire critique du féminisme. PUF, París.2000. Págs. 33 y 54.

${ }^{19}$ Susana Ch., militante política en los primeros '70, activista feminista-INSGENAR (Instituto de Género, Derecho y Desarrollo). Entrevista, 2011.
} 


\section{Cristina Viano}

masculina. Y si bien es cierto que las organizaciones vinculadas al PCR estimularon esa "vigilancia" masculina no todas las mujeres piqueteras estaban de acuerdo en ello, precisamente por sus propias experiencias autonómicas que las había llevado a ellas (no a ellos) a tomar la iniciativa de cortar rutas ${ }^{20}$.

Para Graciela Di Marco ${ }^{21}$ en el encuentro de Salta (2002) la presencia de piqueteras, asambleístas, sindicalistas, campesinas, indígenas, de fábricas recuperadas en suma militantes de movimientos de mujeres diversos marcaba la consolidación de nuevas expresiones del activismo de las mujeres, situación que se intensificaría el año siguiente en Rosario (2003). Allí los derechos relacionados con la salud sexual y reproductiva estuvieron entre los más reclamados; a esa trama hace referencia el siguiente relato.

Bueno reconozco haber opinado sobre el color de los pañuelos... recuerdo una anécdota bien interesante en el taller dónde yo estuve. Nosotras en la Campaña queríamos el aborto seguro, libre. Y hubo en los talleres, en el mío especialmente, un grupo de piqueteras que venían de San Juan y dijeron "pero tiene que ser gratuito también porque sino ¿cómo accedemos nosotras?" Yo dije "esa es una cachetada de clase". Ahí me está marcando lo que a mí no me pareció que hiciera falta pero esta me está planteando que la palabra "gratuito" tiene que estar porque sino miles de mujeres no van a poder acceder. Y ahí nace la palabra "gratuito" en el slogan de la Campaña que antes no estaba y lo hacen las piqueteras. Porque ese encuentro estaba lleno de piqueteras, ese encuentro fue de una composición social totalmente distinta del de los anteriores ${ }^{22}$.

"Esa es una cachetada de clase" resonó en nuestra escucha de una manera peculiar en tiempo real y cuando retomamos a posteriori la entrevista ${ }^{23}$. Su reflexión y su clara memoria sobre la circunstancia marcan a través de un acto que llega vertiginoso y que coloca lo concreto (la cachetada) junto a la clase; es allí precisamente en esa juntura donde se revelan aquellas otras actrices que las extremas injusticias han sabido parir: las piqueteras. Y son ellas las que reclaman eso que aparecía como lo no necesario de plantear, lo no urgente frente a lo urgente. Son las piqueteras las que lo reclaman, esas piqueteras que ya desde hace unos años pueblan los encuentros ${ }^{24}$.

\footnotetext{
${ }^{20}$ Ver al respecto Andújar Andrea; "Rutas argentinas hasta el fin". Mujeres, política y piquetes, 19962001. Ediciones Luxemburg, Buenos Aires, 2014. En prensa.

${ }^{21}$ Ver de la autora El pueblo feminista. Movimientos sociales y lucha de las mujeres en torno a la ciudadanía. Editorial Biblos Sociedad, Buenos Aires, 2011.Págs. 270 y 271.

22 Ídem.

${ }^{23}$ Seguramente Susana lo pensó, aunque señalo que en la entrevista no atinamos a preguntarle si lo manifestó.

${ }^{24}$ Maristella Svampa y Sebastián Pereyra ponen de relieve que desde sus orígenes mismos el movimiento piquetero nunca fue uno ni homogéneo, sino que estuvo atravesado por diferentes tradiciones organizativas y corrientes político ideológicas. Filian sus orígenes donde la desarticulación de los marcos sociales y laborales se realiza de manera brusca y vertiginosa, donde el desarraigo tanto como la desocupación reúne en un solo haz un conglomerado heterogéneo de categorías sociales. En esta dirección subrayan el alto componente de mujeres en las organizaciones piqueteras de base territorial -como la CCC entre otras-desde los momentos iniciales, mujeres a las que retratan desposeídas de experiencia política previa y sin trayectoria laboral en el mercado de trabajo formal. Ver "Las dimensiones de la experiencia piquetera:
} 


\section{Voces (des-encontradas) en los Encuentros Nacionales de Mujeres}

Aunque para entonces otras mujeres, militantes orgánicas de partidos políticos, estaban presentes en los encuentros y en el movimiento. Sin embargo su participación se producía desde una perspectiva personal y no desde una búsqueda de representación político partidaria ${ }^{25}$. Ello no producía choques por la coincidencia en torno a ejes comunes; como la lucha contra la discriminación de género, por la adquisición de derechos o por la legalización del aborto en una comunidad donde se partía y se compartía lo personal como base imprescindible de entendimientos más amplios.

Una etapa donde debatíamos (con mujeres de partidos políticos) desde lo personal más que desde lo institucional y lo político. Íbamos descubriendo cosas que nos pasaban a nosotras. Era cómo esos grupos de conciencia en donde las mujeres se reúnen en absoluta confianza. Después la misma organización del Encuentro se fue politizando con la presión del PTP - PCR. Ahí ya entran con mucha fuerza, cuando se vienen a ofrecer como coordinadoras de todos los grupos las estudiantes de psicología social y nosotras, digamos, como que no previmos la movida política que había detrás. No sé qué opinarás vos de la agrupación esa.(interpela directamente a la entrevistadora)... En esa época solo planteaban el tema de clase, de la pobreza. Ellas el aborto no lo planteaban. ${ }^{26}$

Señalemos que en las entrevistas que realizamos a militantes partidarias de amplia trayectoria en trabajo con mujeres tanto desde lo social como desde la labor legislativa apareció el cuestionamiento hacia el lugar de las mujeres al interior de sus propios espacios políticos; ello no afloró en los relatos de ACP. Los relatos de las feministas son coincidentes en la demarcación de una toma de posición frente a la visualización de un problema: la necesidad de mantener la autonomía ante los intentos de injerencia orgánica de los partidos políticos que como el PCR posee alta capacidad de movilización de mujeres. En general, este cuestionamiento se extendió luego a otras organizaciones de izquierda que más tarde marcarían su presencia y su potencia.

Y me acuerdo que los partidos de izquierda fueron, primero nos criticaron y después fueron a poner la mesita ahí, yo los saqué, los saqué del hall, ¿sabes por qué? No pueden venir a capitalizar esto que es un espacio nuestro, que además lo hicimos con toda... pónganse afuera fenómeno, pero adentro no ${ }^{27}$

El movimiento crecía y crecía pero se cobraba un costo muy alto para las feministas que se sentían impotentes para contrarrestar la fuerza de los aparatos partidarios. Una prueba de ello la constituye que una de las demandas más visibles

Tensiones y marcos comunes en la organización y movilización de desocupados en Argentina" en Revista Trayectorias № 16, Revista de Ciencias sociales, Universidad Autónoma de Nuevo León, Año VI, 2004.

25 Basta recordar que cuando se fundó el primer encuentro la consigna fue "crear un frente de lucha prescindente de nuestras ideologías y de nuestro compromiso en la coyuntura nacional". Calvera, Leonor; Mujer y feminismo en la Argentina, GEL, Buenos Aires, 1990. Pág. 116.

${ }^{26}$ Susana Ch. Entrevista 2011.

27 Mabel G. Militante en los primeros '70, exiliada en Francia, fundadora de Indeso-Mujer. Entrevista 2011. 


\section{Cristina Viano}

(y más "pesada") como el aborto, no podía ser consensuado con ACP ("porque lo que hacían las PCR siempre eran...dejar de lado el debate por el aborto, como tenían un marco de acuerdo con la Iglesia"). El significativo crecimiento de los ENM convocó la atención de sectores sociales fuertemente conservadores; de hecho, las feministas debieron enfrentar el desembarco organizado de las mujeres de la Iglesia Católica apoyado en muchos casos por poderes estatales provinciales. El aborto (en los años '90) quedó confinado a sus persistentes planteamientos y marcaría en adelante uno de los centros de controversia más intensos de los ENM.28 Asimismo, ello se anuda al diagnóstico más general que realizaron varias feministas y que abrió otro frente de batalla significativo; es que durante los años '90 los temas que ganaban los talleres iban "desfeminizándose" y se imponían con fuerza debates sociales y gremiales (también de política nacional e internacional) que si bien enfrentaban en duros combates a distintas organizaciones de las izquierdas partidarias tenían en común el argumento que los debates por los intereses estratégicos de género no debían imponerse a las urgencias que planteaba la gigantesca crisis social argentina, desatendiendo así al hecho más que evidente de que no se trata de cuestiones antagónicas ni sucesivas.

Bueno empezamos a sacar volantes en los Encuentros, eran las diez... las diez cosas del feminismo, no sé qué cosas eran, prejuicios sobre el feminismo, un volante largo que decía todas las cosas que pensaban los demás del feminismo y que no era así... hasta el taller de feminismo empezaba a vaciarse, vaciarse, porque nosotras tampoco íbamos para encontrarnos entre nosotras. Esto después empieza a cambiar, y cuando se arma toda la cuestión del derecho al aborto ahí empieza a reflotar pero a partir de la campaña, siempre hubo articulaciones, de todo el país de todas las mujeres, no tuvimos nunca la organización ni la fuerza necesaria, ni teníamos aparato. ${ }^{29}$

En relación a ACP hemos recogido distintos testimonios que insisten en que "el PCR llevaba sus mujeres, porque además las cuidan y las llevan y las llevan a los talleres que quieren... y nosotras estábamos muy en contra de eso". El retrato de mujeres desprovistas de agencia propia, que solo aparecen guiadas por la mano invisible del partido ya sea por el ejercicio de una actitud paternalista que orienta y cuida y por tanto inhibe la autonomía o bien por el ejercicio de poder que se ejerce a través del manejo de los planes sociales ha sido coincidente entre las

\footnotetext{
${ }^{28} \mathrm{Si}$ bien a partir de las entrevistas que poseemos no podemos explicar acabadamente el explosivo crecimiento de las organizaciones orientadas por el PCR en los años '90 si necesitamos señalar que las mujeres del PCR entablaron una dura confrontación con las manzaneras de la peronista Hilda "Chiche" Duhalde, quienes tuvieron mucho menos éxito para insertarse en el movimiento de mujeres. La disputa más general por las bases sociales con el peronismo, en parte, explica la línea política del PCR que despliega una línea de acción y acumulación donde se retoman ejes reivindicativos hacia las mujeres que eluden entrar en polémica con la Iglesia. Y concomitantemente la negativa a sostener el derecho al aborto. Cabe aclarar que durante el kirchnerismo la organización cambió su posición.

${ }^{29}$ Mabel G. Entrevista, 2011.
} 


\section{Voces (des-encontradas) en los Encuentros Nacionales de Mujeres}

feministas ${ }^{30}$. No obstante, algunas manifestaciones, que si bien no discuten directamente sobre esas convicciones, nos informan sobre otras formas de percibir la participación en los ENM, y que aun sin abandonar un tono general crítico aprecian aspectos obscurecidos en otras perspectivas.

Pueden viajar, está legitimado el ENM. Los convocan los mismos referentes que manejan planes sociales o demás. Entonces mujeres de sectores muy pobres pueden viajar y conocer. Pobres y no tan pobres, que a lo mejor con su ingreso podrían pensarlo. Pero ¿viajar solas? ¿Sin la familia? Cosas impensables. Y ese espacio les da la posibilidad de viajar. Y son experiencias vitales muy poderosas ${ }^{31}$

Por su parte, los relatos de las militantes que se referencian en ACP o en la CCC no pueden establecer un diálogo directo (aunque imaginario) con los de las feministas; sencillamente tienen otras tonalidades y registros que comienzan por sus propias historias de vida, siguen por la incorporación a la militancia a partir de situaciones de pobreza, pérdida de empleo, marginalidad, violencia de género, maternidades y en líneas generales, ponderan muy abierta y positivamente las posibilidades que los ENM suponen tanto en sus vidas personales como para sus prácticas militantes.

Las militantes de ACP no dejan de insistir en la importancia que para ellas poseen los ENM, al punto de atribuirles una condición matricial. El "somos hijas del encuentro" fue una de las expresiones más contundentes que recogimos; también la aseveración que "la mayoría surgimos a partir de haber ido a un Encuentro...". ¿Cuáles son los significados de todo ello? Se desprende que el "surgir" tiene que ver con elementos que hacen al propio empoderamiento individual pero al mismo tiempo colectivo, que cobra una dimensión en la historia personal y en la del grupo de mujeres; que en su mayoría -en este caso- se organizaron alrededor de la coyuntura del 2001. Miriam, militante de la CCC y de ACP contribuye con otra potente afirmación: “una nunca vuelve igual (ríe). Es así. No volvés igual” 32.

Mónica:- Y la mayoría de las mujeres que se involucran un poco con todo esto tiene que ver con... con haber conocido, haber hecho la experiencia de los Encuentros... con lo que implica lo del Encuentro en general, tres días, compartir con otras mujeres, con otras ideologías eh... tanto políticas como religiosas, culturales, económicas eh... o sea, vos compartís... aparte el hecho de irte de tu casa 3 días, dejar

\footnotetext{
30 El siguiente testimonio refuerza la misma idea; "Sí tienen un trabajo que es notable, yo creo que son pensamientos ultras, el PCR tiene ese manejo de mantener rehén a las personas a partir de los planes, a mí eso no me gusta. Yo cuando veo que hay personas que se mantienen rehenes por que hay alguien que los está controlando por una cuota de poder no me gusta. Pero sí Amas de Casa del País tiene un trabajo fuerte en cuanto a concientización pero para mí en grados extremos, llevan a las mujeres a un nivel de radicalización...". Susana B., feminista, militante del Partido Socialista. Entrevista, 2011.

${ }^{31}$ Lucrecia A.

32 Estos aspectos han sido subrayado por varias investigadoras que se han adentrado en las experiencias de organización de mujeres de sectores populares. Ver al respecto Andújar Andrea; op. cit. y Di Marco Graciela; op. cit.
} 


\section{Cristina Viano}

Libia:- Tres no, este año fueron cinco (risas). ${ }^{33}$

Mónica:- Bueno este año fueron cinco. Tres días que... a veces es muy difícil que... sumar a las mujeres, por ejemplo este año que fue un año más largo, que eran más días, se complicó para muchas mujeres el viajar, muchas optaron por no viajar, o sea que salimos, salieron 2 colectivos pero, que podrían haber salido más pero, más mujeres, pero el hecho de los trabajos, muchas mujeres no han podido viajar por condiciones de laborales ...

Eva:- Perdían un día de trabajo.

Mónica:- No se lo daban, en muchas fábricas no se lo daban, perdían viernes y lunes. Y si trabajaban el sábado eran tres..." 34

Los relatos nos informan sobre el significado que posee alejarse unos pocos días de sus obligaciones cotidianas y a tal fin organizarse previamente, tanto desde lo individual como en lo colectivo. Dejar a sus hijas e hijos y para ello, enfrentar los mandatos e imposiciones y también pedir la colaboración para el cuidado de las y los que quedan, en general a otras mujeres o de la familia o bien de la organización. Para algunas de estas mujeres el viaje a los ENM es un hecho excepcional, que tiene un sentido distinto que para las mujeres de clase media, tanto que para muchas ha constituido la primera oportunidad de sus vidas de realizar un viaje, de conocer algunos lugares y en ese marco de gestar, de reforzar o de anudar una sociabilidad con otras mujeres libre de presiones, mandatos $\mathrm{u}$ obligaciones. Resulta muy sugerente cómo aparece la dimensión festiva y la alegría cuando se evocan los ENM. Y ello es fuertemente contrastante además con las valoraciones actuales de muchas de las feministas históricas donde se percibe una suerte de cansancio en relación a los encuentros, una suerte de rutina que se repite. Ello da cuenta asimismo que en cada encuentro se anudan, yuxtaponen, crean y recrean muy distintas experiencias y expectativas.

La realización anual del encuentro funciona como un motor que impulsa a las mujeres a organizarse para asistir; no hay improvisación en ello. Más aún podríamos arriesgar que en el calendario militante de muchas mujeres el viaje al encuentro se ha constituido en el evento más significativo.

\footnotetext{
${ }^{33}$ Se refiere a Bariloche, donde se realizó el ENM en el 2011 y que queda a casi $2000 \mathrm{~km}$ de su ciudad de origen.

${ }^{34}$ Estos fragmentos fueron extraídos de una entrevista colectiva realizada en un local de Amas de Casa del País de Villa Gobernador Gálvez (Provincia de Santa Fe), en cuyo frente hay un cartel que dice "mientras exista un pibe con hambre y una mujer golpeada seguiremos luchando". 2011. No resultó una tarea fácil porque como dijimos fueron entrevistas colectivas (por la propia decisión de las entrevistadas), fueron ellas quienes se organizaron para esperarnos y siempre han participado junto a ellas activistas de una más prolongada militancia partidaria. Como sabemos las entrevistas grupales poseen ventajas y también desventajas. Entre las primeras contamos que la memoria de unas ayudó a las de otras, se dieron mutuamente impulso para contar-nos sus experiencias en un ejercicio que es en extremo infrecuente. Más aún, nos atreveríamos a plantear que ha sido la primera vez en la mayoría de los casos. Por otra parte resulta muy complejo determinar los patrones narrativos de quienes participan menos o muy marginalmente, de quienes son más tímidas o poseen menos recursos expresivos. También la presencia de mujeres provenientes de otros sectores sociales, aunque parte de la misma organización, por momentos guía u orienta la entrevista; no todo el tiempo por suerte. Para ello fue necesario que la entrevista fluyera sin cauce preciso, que el tiempo deviniera, que fuera marcado por un ritmo que se entremezclaba con la actividad del local y la llegada y la salida de un conjunto de mujeres.
} 
(...) mujeres que a lo mejor no han salido de sus casas, siendo amas de casa, toman la iniciativa y por su cuenta van invitando. Y se plantean, que se yo, volantear en las triperías, en las fábricas, para que vayan las mujeres de la fábrica al encuentro, en la puerta del supermercado, en la plaza también, ... es algo que está prácticamente instalado acá, lo del encuentro, que se autosostiene, una comisión que funciona, que se juntan desde distintos... hay una comisión de alojamiento, comisión finanzas, comisión pasajes,... y mientras se va armando lo del viaje, se va hablando de la problemáticas de las mujeres, armar lo del viaje implica que aparecen todos los problemas específicos: "no tengo con quien dejar a los chicos", y bueno, "¿por qué no, con mi esposo?, y prefiero dejar al más chiquito y no a mi hija adolescente", está todo enredado no? en eso, y las mujeres vamos aprendiendo a resolver colectivamente (...) ${ }^{35}$

Llama la atención el señalamiento que la entrevistada hace sobre los lugares por los cuales las mujeres se desplazan para militar y organizar el viaje al encuentro: no solo lugares de trabajo (como fábricas o triperías), sino también la puerta del supermercado, el mercado y la plaza pública; espacios que podríamos pensar con Nancy Fraser como escenarios contrapúblicos subalternos; es decir espacios paralelos donde los sectores sociales subordinados crean y hacen circular contradiscursos para construir interpretaciones oposicionales de sus identidades, intereses y necesidades ${ }^{36}$.

Podrá decírsenos que en tanto las feministas ponen en juego y análisis a la organización y realizan un diagnóstico sobre los alcances que la misma proyecta sobre las vidas de las mujeres, los relatos de las mujeres de ACP nos informan desde su propia experiencia individual y no remiten a la vida de la organización. No obstante, desde registros tan distintos es posible poner bajo sospecha o bajo la carga de la interrogación los efectos atribuidos a la participación de las mujeres como meras transmisoras o apéndices de decisiones externas a ellas, ya que hay un más allá en sus vidas y sus subjetividades que reclama ser explorado. Andrea Andújar37 ha señalado acertadamente que más allá de lo deliberado y buscado por las organizaciones la participación en los encuentros caracterizados por su horizontalidad, por la libertad para nominar y explorar las incomodidades, malestares y sinsabores de las mujeres de manera autónoma a la injerencia masculina estimula a las mujeres a tomar la palabra y hacerse oír en las organizaciones que integran y a actuar en pos de demandas y objetivos comunes en sus propias comunidades. Y tal vez no sea ocioso volver a plantear esta imagen tan potente que nos proveyó una entrevistada: "no volvés igual".

Ese no volver igual nos habilita la pregunta sobre qué efectos se producen tanto en sus vidas privadas como en el plano de los vínculos entre las mujeres de la organización y en el mismo partido. Este interrogante está abierto en el marco de la investigación, por ejemplo para considerar en qué medida la experiencia

\footnotetext{
${ }^{35}$ Laura D. Psicóloga social, militante del PCR/AC. Entrevista, 2011.

${ }^{36} \mathrm{Al}$ respecto ver Fraser Nancy; "Repensando la esfera pública: una contribución a la crítica de la democracia actualmente existente" en Debate Feminista no 4, México, 1993.

${ }^{37}$ Ver Andújar Andrea; op. cit.
} 


\section{Cristina Viano}

militante de las mujeres influyó o no en el cambio de línea del partido en relación al aborto durante el kirchnerismo. Tenemos múltiples evidencias de las dificultades que les acarrea su tratamiento en los barrios: "un tema dificilísimo" sostiene una entrevistada. También subraya que:

ACP no está todo de acuerdo con el tema del aborto, grandes discusiones... grandes discusiones, y entendés que eso es un proceso y después los Encuentros ayudan a discutir y debatir todo eso, me entendés? porque la verdad que vos decís: la consigna del Encuentro es buenísima bah... haber llegado esa consigna se armó desde los Encuentros ${ }^{38}$ y cada vez...en los barrios ... abortan en muy malas condiciones y son las que más riesgo tienen, entonces cuando nosotros planteamos lo del aborto, porque el aborto es un problema social, ¿me entendés? si no se toma, me entendés o sea, no es privado es social y es gravísimo, mueren cientos de mujeres por año, me entendés? por este mismo tema, y bueno en los barrios como ya se sabe, en las condiciones que se hacen son terribles no...10 años atrás hablar del aborto era... nada, todas locas que estaban hablando del aborto, me entendés? que ahora ha sido... el poderlo debatir, encontrarnos todos los años, de recontra debatir los temas y que se yo y bueno, después darte cuenta que hay provincias que avanzan más que otras... bueno eso el Encuentro te lo permite hacer... pero por lo menos también recibir y tener más información de otras provincias ${ }^{39}$.

La llegada de nuevas camadas de militantes provenientes de filas partidarias hacia el año 2001 forma parte de un proceso en continua actualización. Aunque presentes desde antes, las militantes del Partido de Trabajadores Socialistas (PTS) gestaron hacia el 2003 su propia organización de mujeres (Pan y Rosas) ${ }^{40}$ irrumpiendo con estridencia y gestos provocativos en los ENM.

Pan y Rosas es una organización muy distinta a ACP y tal vez uno de los pocos vínculos que pueda encontrarse entre ambas tiene que ver con que ninguna de las organizaciones se define como feminista. La articulación entre la clase y el género pero también la subordinación del género a la clase es una característica política fuerte de Pan y Rosas; no se habla en nombre de las mujeres todas, sino que la organización asume explícitamente que su referencialidad se dirige a las mujeres explotadas, trabajadoras, pobres, oprimidas. A propósito de ello el siguiente testimonio es muy elocuente:

\footnotetext{
${ }^{38}$ La entrevistada se refiere a la consigna central de la Campaña Nacional por el Derecho al Aborto Legal, Seguro y Gratuito: "Educación sexual para decidir, anticonceptivos para no abortar, aborto legal para no morir".

${ }^{39}$ Liliana Z. Militante de ACP. Entrevista, 2011.

40 "La agrupación de mujeres Pan y Rosas se formó a partir del Encuentro Nacional de Mujeres del 2003, en la ciudad de Rosario, con compañeras del Partido de Trabajadores Socialistas (PTS) y estudiantes y trabajadoras independientes, que participamos unitariamente en aquella oportunidad, planteando la lucha por el derecho al aborto y los derechos de las mujeres trabajadoras. Pan y Rosas considera que la lucha contra la opresión de las mujeres es, también, una lucha anticapitalista, y que por eso, sólo la revolución social encabezada por millones de trabajadoras y trabajadores en alianza con el pueblo pobre y todos los sectores oprimidos por este sistema, que acabe con las cadenas del capital, puede sentar las bases para la emancipación de las mujeres". Ver www.pyr.org.ar.
} 


\section{Voces (des-encontradas) en los Encuentros Nacionales de Mujeres}

(...) yo te iba a contar algunas cosas no porque es una discusión abierta adentro del partido, por ejemplo nos surgió si las compañeras LGTB y los compañeros LGTB iban a estar en el mismo espacio político que Pan y Rosas, cuando en realidad es una organización de mujeres y son aspectos de opresión diferentes en algún sentido y en otros ser lesbiana y tener que abortar, son problemas comunes pero diferentes. Entonces surgieron discusiones profundas con respecto a esto donde pensamos bueno no sé impulsamos una organización LGTBI específica, ¿es la clave? Un montón de discusiones pero también pensar de qué hablamos cuando hablamos de este tipo de discusión, de qué hablamos cuando hablamos de mujeres decimos que somos doblemente oprimidas por ser mujer y por ser parte de una clase, porque si bien no todas las mujeres somos iguales, entonces nosotras no estamos con las.. entonces no somos feministas, no estamos con las mujeres como Mirtha Legrand, como Amalita (Fortabat)... ${ }^{41}$

Las militantes de Pan y Rosas han puesto en discusión algunos aspectos del funcionamiento de los ENM y ello las ha llevado a confrontar duramente con las militantes de ACP/PCR, con otros grupos feministas y también (con sus propios argumentos y estrategias) con las militantes de la Iglesia Católica que en forma muy organizada irrumpen en los ENM al menos desde el encuentro de San Juan en el año 1997.

Cuando se inicia cada encuentro se reparte una carpeta (que ha sido acordada en el seno de la Comisión Organizadora), donde aparecen los distintos talleres y una mínima orientación sobre su contenido. Si un taller cuenta con más de 40 mujeres, se divide. Hay una coordinadora por taller y para participar en la elaboración de las conclusiones, es un requisito haber estado en toda la discusión. No se vota, se elaboran síntesis de acuerdo a los consensos. Las temáticas van apareciendo y desapareciendo, cambian el nombre, algunos espacios surgen como necesidades y se autoconvocan al principio y luego integran la nómina oficial, de acuerdo a las variantes propias de los avances, las luchas y los acuerdos y desacuerdos en la Comisión Organizadora ${ }^{42}$.

Los señalamientos y las críticas de las militantes de Pan y Rosas se desplazan en variadas direcciones. Al tiempo que se reconoce la importancia del Encuentro ("que miles de mujeres vayan a un espacio y puedan discutir, extraer experiencia, etc., etc."), se cuestiona la matriz misma de la organización que ha adoptado la modalidad del consenso al interior de los talleres. Insisten en impugnar esto en cada comisión organizadora de la que han podido participar y en cada taller de los ENM. Votar decisiones y planes de lucha concretos aparece para ellas como una tarea urgente e impostergable frente a la modalidad del consenso que goza de una amplia aceptación y de larga tradición.

(...) pero ¿adónde vamos?, nosotros queremos salir, denunciar y accionar y salir con un plan de lucha, son políticas diferentes en ese punto...Ahora lo que nosotros decimos que esos encuentros con todo el esfuerzo que significan y todo el encuentro que significa eso, pueda ser un espacio donde se puedan discutir de forma

\footnotetext{
${ }^{41}$ Entrevista a Belem, militante de Pan y Rosas y PTS. Estudiante universitaria, 2012.

42 Ver Alma y Lorenzo, op cit.
} 


\section{Cristina Viano}

democrática, desde abajo hacia arriba en forma de los talleres y demás eh... determinadas acciones inclusive donde se pueda hacer una continuidad con... donde se puedan votar planes de lucha concretos, planes de lucha para pensar bueno si en el encuentro de mujeres votamos y discutimos la necesidad de levantar la lucha por el derecho al aborto, o sea que voten veinte mil mujeres que viajan, no sé cuántas son, pero son... en la marcha de los cierres son veinte mil. ...que para nosotros es el método democrático, una persona un voto, de poder discutir... el método del consenso en sí mismo cuando no... no sé qué es el consenso, dónde están las diferencias, dónde están las... qué se yo... que se lleguen a posiciones de minorías si hacen falta pero que se pueda votar, que es el método más democrático, el método que han conquistado nuestros compañeros en su lugar de trabajos, cuando hacen asambleas y votan y votan mociones y planes de lucha. Nosotros las mujeres tenemos que también tomar esos métodos que han sabido construir en la historia las organizaciones más democráticas que son de los sectores de trabajadores... ${ }^{43}$

La jerarquía de la Iglesia Católica viene desplegando un conjunto de estrategias muy ofensivas hacia los ENM, que van desde campañas publicitarias en los medios masivos de comunicación a irrupción e interrupción de los debates de los talleres que tratan el aborto hasta agresiones organizadas. Si bien anticoncepción y aborto constituyen los temas más ríspidos "el ataque a la familia y los valores tradicionales" también preocupa a la Iglesia. El boicot organizado y sistemático a los ENM ha generado distintas posiciones y actitudes.

Examinemos los argumentos de las militantes de Pan y Rosas y también los de las feministas. Las primeras señalan que a ellas no se les ocurriría concurrir a un encuentro de Acción Católica ni a un retiro espiritual; esta comparación es un modo de mostrar la ajenidad de esas otras mujeres. No de las creyentes en general sino solo de aquellas que concurren organizadamente para boicotear los encuentros. Reconocen que la composición de la iglesia católica es heterogénea, tanto que involucra desde las Católicas por el Derecho a Decidir a mujeres del Opus Dei, pero estas últimas no deberían formar parte de los ENM. Claramente exponen que no debería permitírseles participar en los encuentros porque "(...) el Opus Dei, yo creo que es la parte de la iglesia, la peor parte, de derecha, cómplice de masacres, debería estar en el banquillo de acusados por la dictadura militar, que no, ¿qué tengo que acordar con ese sector? Nada"44.

Cecilia argumenta que "si los Encuentros de Mujeres tienen en su perspectiva liberar a las mujeres de su opresión, aquellos que quieran no sólo no liberarlas, sino mandarlas a la Edad Media no deberían participar, porque va en contra del objetivo mismo de hacer Encuentros de Mujeres" ${ }^{\prime 5}$. El problema se saldaría si en los encuentros se pudiera votar: las alimenta la común convicción que la posición de la Iglesia sería derrotada.

En palabras de las feministas, la actitud beligerante contra las militantes de la iglesia es una práctica autoritaria y patriarcal que arrastran las militantes de los partidos de izquierda en general

\footnotetext{
43 Belem, entrevista, 2012.

44 Ídem anterior.

45 Entrevista a Cecilia; estudiante universitaria, militante de Pan y Rosas y PTS, 2012.
} 
(...) se han incrementado, algunas tendencias que me gustaría que desaparecieran adentro del movimiento, como el fundamentalismo feminista. Que después en el encuentro siguiente me entero de que hubo gritos, golpes con mujeres conservadoras y nunca el grito puede reemplazar al debate sino podes ganar un debate tenés que ir a buscar más argumentos. 0 tenés que estudiar más, reflexionar más pero no podés cerrarle la ventana a una mujer, tirarle yerba; porque es ultracatólica o conservadora. Y esa tendencia la traen también las jóvenes de izquierda que vienen al encuentro totalmente empapadas en el autoritarismo de los partidos políticos. Sin revisar toda esa formación patriarcal que ellas traen se meten al encuentro e imponen determinadas modalidades y me parece que es una macana por que la censura te empobrece, la censura no favorece el debate, te empequeñece y bueno. ${ }^{46}$

Asimismo, las feministas ponen de relieve otro aspecto sobre las militantes provenientes tanto del PCR como del PTS (aunque la crítica no las alcanza solo a ellas en esto): el hecho de que los ENM se constituyan en el escenario de confrontación de líneas políticas en las que las problemáticas que atraviesan a las mujeres no está insinuada o bien aparece solo en ciertos resquicios y frente a determinadas problemáticas puntuales sin llegar a conmover, atravesar o teñir un horizonte político y social más general.

\section{Algunas consideraciones finales}

Si bien las entrevistadas conforman un heterogéneo universo tanto en lo atinente a sus procedencias sociales, sus trayectorias personales, las organizaciones a las que pertenecen, sus franjas etarias, en suma a sus historias de vida, hay un elemento que resulta común: todas ellas se han organizado o están organizadas actualmente en grupos $u$ organizaciones de mujeres, territoriales, sindicales o políticas. Vale decir que más allá de las distintas divisiones del trabajo militante al interior de sus organizaciones (sobre todo en las que nuclean mujeres $\mathrm{y}$ varones), todas han salido al espacio público y han roto de un modo u otro el cerco del mundo privado agenciándose para alterar los contornos de la opresión de género.

Hemos atravesado relatos de mujeres que provienen de organizaciones políticas muy distintas tanto en sus definiciones ideológicas (referenciada una en el campo del maoísmo y otra en el del trotskismo), como en sus modos de organización, en sus marcos de acuerdos y alianzas, en sus búsquedas más generales, en los sectores sobre los que se afianzan y nutren, y por supuesto, en las maneras de concebir el trabajo y las perspectivas de género. Tanto ACP/CCC/PCR y Pan y Rosas/PTS son organizaciones de alcance nacional; la primera con fuerte desarrollo territorial y amplias bases sociales, la segunda con un anclaje social más acotado, con una fuerte apelación a la clase trabajadora y más actualmente con una pequeña representación parlamentaria al interior de un frente de izquierda

\footnotetext{
46 Entrevista a Susana Ch., 2011.
} 


\section{Cristina Viano}

(Frente de Izquierda y de los Trabajadores-FIT). Las hemos puesto en diálogo con voces de mujeres que provienen de grupos feministas que asomaron a la acción colectiva sobre la primera mitad de los años '80. Y en esa dirección, consideramos el balance que realizara Irene 047. Balance que no deja de interpelarnos cuando sostiene que aunque de eso mucho no se habla "alteran los encuentros" pero al mismo tiempo “(...) si no fuesen ellas no sé quien más podría mantener el encuentro de mujeres porque si fuese por las feministas ya habrían 28 encuentros de mujeres distintos".

El recorte analítico que hemos realizado pone de manifiesto la tensión existente entre las estructuras partidarias que traen consigo un cierto modo de hacer política "con las mujeres" y no "desde las mujeres" como se propone desde los ENM, pero es apenas eso: un recorte en los relatos de mujeres que traman incansablemente sus vidas a partir de prácticas militantes que están impregnadas por escenas que desnudan realidades, describen experiencias, ensayan pensamientos y reflexiones desafiantes y diversas. Ello nos obliga a desarmarlos, a bucear en sus intersticios y a confrontarlos para rearmar un mosaico que al modo de un nuevo relato asuma esa diversidad que compone hoy al movimiento de mujeres en Argentina y que por supuesto no se agota (ni de lejos) en las organizaciones y espacios de los que nos hemos ocupado.

\section{Siglas}
ACP Amas de Casa del País
CCC Corriente Clasista y Combativa
PCR Partido Comunista Revolucionario
PTS Partido de los Trabajadores Socialistas
RIMA Red Informativa de Mujeres de Argentina

\section{Bibliografía}

ANDUJAR, Andrea; "Rutas argentinas hasta el fin". Mujeres, política y piquetes, 19962001. Ediciones Luxemburg, Buenos Aires, 2014. En prensa.

ALMA, Amanda y Paula LORENZO; Mujeres que se encuentran. Una recuperación histórica de los Encuentros Nacionales de Mujeres en Argentina (1986-2005), Feminaria Editora, Argentina, 2009.

ANZORENA, Claudia; "De ciudadanas a administradoras. Reflexiones en torno a la relación entre mujeres y Estado en los últimos 25 años en Argentina" en ESPINOSA MIÑOSO, Yuderkys (coord.) Aproximaciones críticas a las prácticas teórico-políticas del feminismo latinoamericano. Vol 1. En la frontera, Buenos Aires, 2010.

BORTOLOTTI, Mariana, FIGUEROA Noelia y Cristina VIANO; "Los años '80. Los primeros pasos de una nueva etapa" en VIANO Cristina (coord.); Des-bordando los

\footnotetext{
${ }^{47}$ Entrevista a Irene 0. 2011. RIMA (Red Informativa de Mujeres de Argentina).
} 


\section{Voces (des-encontradas) en los Encuentros Nacionales de Mujeres}

márgenes. El movimiento de mujeres en el Gran Rosario. Homo Sapiens ediciones, Rosario, 2014. En prensa.

CALVERA, Leonor; Mujer y feminismo en la Argentina, GEL, Buenos Aires, 1990.

DI MARCO Graciela; El pueblo feminista. Movimientos sociales y lucha de las mujeres en torno a la ciudadanía. Editorial Biblos Sociedad, Buenos Aires, 2011.

FALQUET, Jules; "La división sexual del trabajo militante: reflexiones en base a la participación de las mujeres en el proceso revolucionario en El Salvador (19811992)" en FEMENIAS, María Luisa (comp.); Perfiles del feminismo iberoamericano. Vol. 3. Catálogos, Buenos Aires, 2007.

FRASER, Nancy; "Repensando la esfera pública: una contribución a la crítica de la democracia actualmente existente" en Debate Feminista no 4, México, 1993.

GARCIA, Carmen Teresa y Magdalena VALDIVIESO; "Una aproximación al Movimiento de Mujeres en América Latina. De los grupos de autoconciencia a las redes transnacionales" en OSAL; CLACSO Año VI № 18, Buenos Aires, 2006.

GRAMMATICO, Karin; “Las mujeres políticas y las feministas en los tempranos' 70. ¿Un diálogo (im)posible?” en AA.VV Historia, género y política en los '70. Universidad de Buenos Aires y Feminaria Ediciones, Buenos Aires, 2005.

MASSON, Laura; Feministas por todas partes. Una etnografía de espacios y narrativas feministas en Argentina. Prometeo libros, Buenos Aires, 2007.

MAFFIA, Diana, PEKER Luciana, MORENO Aluminé y MORRONI, Laura editoras. Mujeres pariendo historia. Cómo se gestó el Primer Encuentro Nacional de Mujeres. Reseña íntima y política de las integrantes de la Comisión promotora. Imprenta de la Legislatura de la CABA, Buenos Aires, 2013.

PITA, Valeria; "Voces en conflicto, espacios en disputa. Experiencias feministas en la Argentina de los '90" en Feminaria; vol. XIII, Buenos Aires, 2007.

RÍOS, Guillermo; "Narrar después. Fragmentos y prácticas en la constitución del movimiento de mujeres en la ciudad de Rosario" en CD X Encuentro Nacional y IV Congreso Internacional de Historia Oral de la República Argentina, Esas Voces que nos llegan del pasado, Universidad Nacional de San Luis. San Luis, 2011.

SVAMPA, Maristella y Sebastian PEREYRA "Las dimensiones de la experiencia piquetera: Tensiones y marcos comunes en la organización y movilización de desocupados en Argentina" en Revista Trayectorias № 16, Revista de Ciencias sociales, Universidad Autónoma de Nuevo León, Año VI, 2004.

VASALLO, Alejandra; "Las mujeres dicen basta: movilización política y organizaciones feministas argentinas en los años '70" en AA.VV Historia, género y política en los '70, Universidad de Buenos Aires y Feminaria Ediciones, Buenos Aires, 2005. 